\title{
The Experience of Place in the Annual Festival Held in an Amazigh Village in Southern Tunisia
}

\author{
Tamaki Kitagawa
}

\footnotetext{
check for updates

Citation: Kitagawa, T. The

Experience of Place in the Annual Festival Held in an Amazigh Village in Southern Tunisia. Sustainability 2021, 13, 5479. https://doi.org/ $10.3390 /$ su13105479
}

Academic Editors: Shangyi Zhou, Shaoming Lu and Nikolaos Boukas

Received: 26 March 2021

Accepted: 7 May 2021

Published: 13 May 2021

Publisher's Note: MDPI stays neutral with regard to jurisdictional claims in published maps and institutional affiliations.

Copyright: (C) 2021 by the author. Licensee MDPI, Basel, Switzerland. This article is an open access article distributed under the terms and conditions of the Creative Commons Attribution (CC BY) license (https:// creativecommons.org/licenses/by/ $4.0 /)$.
Alliance for Research on the Mediterranean and North Africa, University of Tsukuba, Ibaraki 305-8577, Japan; kitagawa.tamaki.kb@u.tsukuba.ac.jp; Tel.: +81-(0)29-853-3982

\begin{abstract}
The phenomenological meaning of place argued by Yi-Fu Tuan and Edward Relph involves multiple disciplines, including religious studies. Based on the idea of experience of place, the study examines the structural contrast between the inner village and the outside suburbs. Focusing on the representation of the contrast of places in the festival of southern Tunisia, it also discusses the inner and the outer experience of the human existence that such contrast implies. In this regard, interviews with the local people in the village and observation of rituals and festivals were implemented. The traditional rituals designate the contrast of the human realm and the untamed nature, which has been shaped by environmental and historical factors. Their ambivalent ontological orientations toward usefulness/controllability and toward sacredness/uncontrollability are reconciled by the experience of the festival. The dynamism of the inside and the outside in the form of olives, a bride, or a palanquin enables people to realize the source of new lives and experience the essential meaning of generation. In spite of recent political and exhibitionistic tendencies, the Mahrajān represents the universal structure of festivals in which arbitrariness is periodically broken down by introducing the external sacredness into the inner human realm.
\end{abstract}

Keywords: experience of place; phenomenology of place; history of religion; festival; southern Tunisia; Amazigh

\section{Introduction}

Today's landscape theory is not limited to cultural geography; rather it functions as a nexus of issues with architecture, urban engineering, tourism, cultural preservation, and many other fields. Tuan [1] and Relph [2], who were among the first scholars to discuss the phenomenological meaning of place in geographic research, deepened their consideration of the experience of space pioneering subsequent landscape theory. Their discussions on place have involved multiple disciplines, including religious studies. The consideration of religious experience is essential to the subject of cultural geography: in what ways people, given the human endowment, attach meaning to and organize space and place [2] (p. 5). This is because, in traditional societies, the most important matters have been considered to be in the "religious" category. With religious sensibility, there are two main universal places in human experience: "this world," where we live daily, and the "other world," where souls after death and spiritual beings belong. Such understandings of the world often influence their social and personal lives. However, the subject of cultural geography has not been sufficiently discussed from the perspective of religious studies. Therefore, considering theories of religious studies, this paper can pose two questions on this subject. First, the dichotomies of the sacred and the profane, or "this world" and the "other world," may be placed at the root of human experience as dynamism of inside and outside. Secondly, in traditional societies facing transformation, the dynamism may be experienced even in the context of modern events. Thus, this paper critically examines the ideas of place in cultural geography from the standpoint of the history of religion and contrasts experiences of two places: the village and the suburbs (i.e., the wilderness) represented in the festival of southern Tunisia. 
Today, our lives are more or less caught between the traditional mode of behavior which is socially, historically, and culturally sustainable, and the modern mode of behavior which has completely different values from the former. In Tunisia, agricultural rituals and customs related to olive cultivation are currently on the decline due to rural development and the diffusion of fundamentalism, especially in the northern and central coastal areas. Meanwhile, in southern Tunisia, olive cultivation has been extremely limited in terms of quantity and productivity because of the environmental obstacles for extensive irrigation. The olive industry in the south has not grown beyond the level of subsistence, which has forced the region to rely on tourism and migrant labor as its main sources of cash income. Consequently, southern Tunisia (especially in the less-developed Amazigh villages) has continued to preserve its indigenous cultures based on traditional olive and stock-farming lifestyles while suffering from the need to transform its traditions due to modernization. In particular, tourism changes the meaning of the landscape around them. Sacred mountains and caves and practices once carried out according to precise symbolisms become touristic resources to attract foreigners and rich Tunisians. Outsiders can consume landscapes without involving themselves in the region's unique and inherent meanings [2] (p. 85). Does tourism reduce the meaning of places, even in the experience of the local people? For local people, acceptance and use of tourism is a threat to the decline of their traditional way of life [3,4], but it is also a compromised option to continue their traditional life [5].

The Mahrajān festivals in Tunisia are generally government-created events that highlight the local traditions or specialties as tourism or industrial resource. Conversely, the new Mahrajān festival in an Amazigh village was spontaneously created by the residents. While the festival started as a touristic event, it is represented with prayers for a bountiful olive harvest and the prosperity of human fertility. A new festival created in the conflict between tourism and traditional behavior may reflect their traditional view of place while showing their flexible transformation to new situations. If so, it may be presumed that the ontological dynamism from the outside to the inside and vice versa is expressed in the core of the festival as in traditional agricultural rituals. Thus, based on the review of the literature and observation of the festival, the specific purpose of the present study is three fold: (1) to examine the structural contrast between the inner village and the outside suburbs; (2) to focus on the representation of the contrast of places in the festival; and (3) to discuss the inner and outer experience of the human existence that such contrast implies.

This paper examines the idea of the experience of place in cultural geography from the perspective of history of religion to reveal the continuity between the theory of passions on which the idea rests and the interpretation of religious experience. By interpreting the experience of place in history of religion using a specific example of a festival, it aims to show how religious experience shapes their lives, personalities, and their society. Thereby, it aims to fill the research gap between cultural geography and religious studies and provide a more existential understanding of the human experience of place.

\section{Phenomenological Understanding of Place and Religious Experience}

In Place and Placelessness (2008/1976), Relph examined the notion of place, as a phenomenon of "the lived-world of our every day," by identifying the diverse ways in which place is experienced and contrasting it with placelessness, as the formation of an impersonal, standardized landscape. He also used phenomenology as his approach and considered "the various ways in which places manifest themselves in our experiences or consciousness of the lived-world, and with the distinctive and essential components of place and placelessness as they are expressed in landscape," based on the recognition that "these proceed from an acceptance both of the wholeness and indivisibility of human experience, and of the fact that meaning defined by human intentions is central to all our existence" [2] (pp. 6-7). In addition, he made significant contributions to the field of geography by providing a comprehensive overview of diverse regions and cultures, including Aboriginal Australians, Native Americans, the people of the Trobriand Islands, and those of South Wales, and by 
discussing the geographical perceptions of these societies as "experiences of place". This methodology had not been systematically used in geography until then.

Conversely, there have been many criticisms regarding his definition and discussion of place and placelessness, with the main criticisms including its essentialistic attitude, its deviation from the reality of places today, and its simplistic dualism that narrows our understanding of the experience of place [6]. From the standpoint of the history of religion, the problem with his theory lies in its insufficient phenomenological attitude, which is indirectly related to the above criticisms. For example, in Chapter 5, he defined the "sense of place and authentic place-making" and differentiated the terms "authenticity" and "inauthenticity," based on social thinker John Ruskin's concept of "true life" and "false life." He also stated that true life "never forfeits its own authority as a judging principle," while false life "is overlaid by the weight of things external to it" [2] (p. 63).

Regardless of the validity of the arguments emanating from the modern view of human beings by Ruskin, the problem is that both Relph and Ruskin treat authenticity and inauthenticity as something as substantive as "life." Such an attitude is quite different from the phenomenological approach, which focuses on the existential character of the phenomenon itself, after stopping to consider a thing as a substance and suspending judgment on the rightness or wrongness of its content (epoché). Rather, it is what philosopher Edmund Husserl called "natural standpoint" [7] (pp. 51-52). Moreover, if we take a phenomenological approach, then we must treat phenomena as something that "seems real" or "seems fake" to the target people and society and analyze the structures that give rise to these distinctions and consider the meanings of these experiences. In this way, a new dimension of meaning (i.e., a new interpretation) arises, which could not be known either from one's own natural standpoint or from objective perception. Hence, the distinctions Relph used are based on his substantive "natural standpoint" by which Relph considered something that "seems real" to him as "authenticity" and something that "seems fake" to him as "inauthenticity."

Another problem with Relph's phenomenological understanding of place, from the standpoint of religious studies, is his modern view of human beings. For instance, Relph stated, "They are no less important for that, for it is these personal experiences of space that are the basis for much of the meaning that environments and landscapes have for us. Through particular encounters and experiences, perceptual space is richly differentiated into places, or centers of special personal significance" [2] (p. 11). In other words, Relph's understanding of the experience of place is caught in the limitations of the modern conception of human beings, either by setting it on a personal phase or by making the natural environment the "object" with which the individual confronts. It is well-known that many of the examples that he cited as "authentic" are experiences of place in primitive societies, where individuals do not exist as they do in modern societies. It has also been pointed out in anthropology that the "individual" in the traditional world is not an indivisible individual, but "dividual," i.e., a divisible personality in which people are subjected to various materials and ontological influences from others (such as people, things, gods, lands). At the same time, people exude elements of themselves toward others through everyday interactions such as meals and conversations [8-10].

Meanwhile, the experience of humanity, which is common to that of individuals, is important for considering phenomenological methods as well as the examples that Relph adopted. As the meaning of phenomenology lies in the question of how individual experience is related to what is important to humanity as a whole and how individual experience can become a universal meaning common to humanity, it would be difficult to achieve the goal of exploring the common experience of humanity if the sharing of the experience is taken as a secondary concern. In primitive societies, and even in traditional societies, the significance is on the meaning of the individual in the context of the world and the community, rather than the individual him/herself. In this way, the individual can acquire a religious significance because the representations in the religious realm show us explicitly that individual experiences can be given human meaning. For example, the 
daily act of eating bread can have a universal meaning when we receive it as a gift from God in heaven, the children of the Earth mother, or the body of God. Thus, in discussing the experience of place, it is essential to understand how it is religiously represented and experienced in a given culture.

It should be noted that the history of religion is not the study of what is generally regarded as "religion" such as doctrines or religious organizations, but it is an attempt to understand human beings and the world from the reality of religious experience. Through its process, the meaning of "religious attitude" and "religious experience" as human existence is clarified. Moreover, the things that have been most important to humans have been represented religiously. In this regard, components of the world such as air, sky, earth, food, water, trees, life have been created in an unknown place and time and brought into this world. However, they did not necessarily acquire the form of a "religion" in the narrow sense of the word. Meanwhile, religious attitudes have been observed in basic human activities, such as eating, sex, sleep, and language, as well as in songs, stories, pictures, rules, cures, acts of exchange, and a wide array of human activities surrounding death and birth.

In describing sacred space, Relph stated, "For the religious person, the experience of such space is primordial, equivalent perhaps to an experience of the founding of the world, and it follows that the making of sacred objects and sacred buildings is not a task to be undertaken lightly but involves a profound and total commitment" [2] (p. 15), drawing on the ideas of Mircea Eliade, the historian of religion. Of course, "total commitment" refers to one's involvement in sacred creation, which indicates the relationship between the sacred and the human. Eliade also named the manifestation of the sacred as "hierophany," and claimed that it is the occasion for the renewal of the world. As the manifestation of the sacred creates a new world around it, hierophany always occurs in the center of the world. Although Relph did not elaborate on what the manifestation of the sacred actually is, it is quoted as "the manifestation of something of a wholly different order" [11] (p. 11).

The sense of otherworldliness is a central element in the experience of the sacred, and it has often been presented in the vertical ontology of monotheistic religions, as in the sky or steeples of churches. In other religious forms, or even within monotheistic religions, the "other world" can be understood in different ways, such as the idea of Pure Land in Buddhism, Arcadia, Fortunate Isles, or the underground world that stretches from caves. While Relph eliminated it from his quotation, the essence of Eliade's theory of hierophany is that the sacred appears in the mundane realm: "the manifestation of something of a wholly different order, a reality that does not belong to our world, in objects that are an integral part of our natural 'profane' world" [11].

The sacred not only appears in places designated by society as "sanctuaries" but also in the secular realm. Compared to sacredness itself, the entire world seems "secular." In this sense, the sacred always appears in the "secular" realm, and the manifestation of the sacred makes the world a "sacred" realm. In other words, as we cannot live without a certain orientation, we have given the name "sacred" to this orientation. Thus, to consider that orientation can be found in a place set as "sacred" is a perversion of this ontological order. Moreover, the sacred is not a segment or result of human activities. For instance, prayers and rituals are perceived as causing the manifestation of the sacred, but in fact, the opposite is true: we pray because it exists, and we perform rituals because it appears. The sacred appears as something essentially apart from human intent (i.e., something free from causality). In this regard, it is important to point out that there is a gap between the anthropocentrism in Relph's perception discussed at the beginning of this section, i.e., the "meaning defined by human intentions is central to all our existence" [2] (p. 7), and the experience of places that make him feel "authentic."

Contrastingly, in Space and Place: The Perspective of Experience (2018/1977), Tuan did not discuss individual experience, but essentially "our" experience (i.e., the experience of humans as complex beings). He focused on the question of "how the human person, who is animal, fantasist, and computer combined, experiences and understands the world," and 
attempted to find "shared traits that transcend cultural particularities and may therefore reflect the general human condition" [1] (p. 5). This attempt to grasp the human experience that underlies primitive, traditional, and modern societies can be said to have a perspective on human history that goes beyond the theory of modern humanism that focuses on individuality. Tuan also considered that "experience is directed to the external world. Seeing and thinking clearly reach out beyond the self" [1] (p. 9). In other words, seeing, speaking, and thinking are clearly out of oneself, which is an understanding of humans that is equivalent to the "dividuality" proposed by Marriot [8].

Furthermore, Tuan cited philosopher Paul Ricoeur's reflections on emotions that "Feeling is ... a very strange intentionality which on the one hand designates qualities felt on things, on persons, on the world, and on the other hand manifests and reveals the way in which the self is inwardly affected," and concluded that "in feeling 'an intention and an affection coincide in the same experience'" [1] (p. 9). Ricoeur's standpoint is based on his theory on passions. Although in the descent of philosopher René Descartes on "the passions," Ricoeur did not leave the existence of the shock of emotion to the body, which exists exclusively in opposition to the mind. Instead, he argued that emotion "brings about a living passage from a nascent thought to a corporeal agitation," and that emotions are triggered by a quick evaluation toward thoughts and perceptions that are implicitly present in us, but outside of our volitional control. In short, he stated, "emotion does not refer back to the reflex mechanism which functions between body and body, but to the mystery of the union of the soul and the body" [12] (p. 269). This understanding of emotions by Ricoeur reveals the state that we are in when we experience something. In other words, when an emotion arises, it is exposed to external influences, and it occurs as a "shock" that does not involve volitional control but always involves non-explicit thoughts such as previously developed judgment criteria. It is also said to be a "circular phenomenon" in the sense that the emotions generated by such thoughts further influence one's own thoughts. Hence, Tuan stated, "the given cannot be known in itself. What can be known is a reality that is a construct of experience, a creation of feeling and thought" [1] (p. 9).

Tuan's consistent discussion of the experience of place seems to primarily rest on Ricoeur's interpretation, i.e., the union of the mind and body in emotions, and the creation and congruence of emotions and thoughts in the reality of experience. Such experiences, in the sense that they are far removed from volitional control, are closer to "numinous consciousness," which Otto posited as a sui generis element of religious experience [13] (p. 7). Meanwhile, the coincidence of intention and affection in experience includes the same structure as the "principle of participation" [14] (pp. 68-110), [15] (pp. 84-110), where the object emerges in the self and the self in the object, or the "dividual" personality, which is the structure of the aforementioned manifestation of the sacred in the secular realm.

As for the sacred, it not only breaks down the old world but also the old shell of the self because it creates a new self and world that are connected to each other in a brand-new way. This correspondence between the self and the world in various religious traditions is based on this experience of self-world renewal [11] (pp. 165-167). Tuan explored the human experience of place, and by focusing on the reality of such experience, we can point out that it includes the same structure as religious experience. For example, when we stop reducing experience to something other than existence, such as society, economics, politics, etc., what becomes clear is the fundamental character of experience itself, i.e., the sense that it is completely beyond our comprehension and is something that can be identified as the "wholly other" (das "Ganz andere"), which is common to all religious experience [13] (pp. 25-30). In this sense, any human experience can be religious experience, and religious experience is the archetype of all human experience.

Finally, Tuan explained the value of space as "the human being, by his mere presence, imposes a schema on space. Most of the time he is not aware of it" [1] (pp. 36-37). This "schema" is the sense of orientation (i.e., the left and right as well as the center and periphery) that is so commonly experienced from infancy that we are unaware of it in our daily lives. However, "ritual occasions ... lift life above the ordinary and so force him 
to an awareness of life's values" [1] (pp. 36-37). By experiencing a reality that surpasses everyday meaning in ritual occasions (i.e., by elevating life from its everyday value), the essential value of life can be revealed. It also means that the mundane, everyday world will regain its original meaning and the various values of life. For example, when palanquins lead a procession through the entire village at a festival, the overwhelming reality of the unusual, i.e., the colorful decorations, the noisy music, the continuous alternation of dances, and the various ritual procedures, takes the village street out of the context of everyday life and redefines it as "the path of the palanquins." As the palanquins proceed, the street is transformed from its mundane meaning into a space based on "otherworldliness," a place where divine things (in this case, the palanquins) pass through. It also reveals that space is a cosmos that manifests its center, which is the essential meaning of the place. In the following section, I consider what type of reality is acquired and what type of spatial representation is used to experience the place in a festival held in an Amazigh village (hereafter referred to as "Village $\mathrm{T}^{\text {") }}$ in southern Tunisia.

\section{Methodology}

This research was initiated as part of a study to understand the reality of agricultural rituals and saint veneration in Tunisia. In this study, fieldwork was conducted on 20-30 August 2014, 1-7 December 2014, 14-30 July 2015, 14-25 May 2016, 19-28 July 2016, 10-22 January 2017, 13-20 May 2017, and 2-14 August 2017 to observe and collect information on the Mahrajān and other customs in Village T and other villages. The interviews were conducted in English, Arabic, and Amazigh with translators on-site for native Arabic and Amazigh speakers. During the first two sessions, the author conducted preliminary research using a questionnaire on their knowledge about six categories: traditional songs, rituals, symbols, myths and legends, taboos, and folk medicine, especially related to olive cultivation. The survey sheets were distributed to local people in the governorates of Tunis, Sousse, Monastir, Gabes, Medenine, and Tozeur. Information collected from the survey responses in the mountainous areas of Gabes province shows that they preserve their traditional agricultural rituals and practices. The main fieldwork was then focused on Village $\mathrm{T}$ and the surrounding communities because it is an Amazigh-speaking village, and they did not accept mass resettlement in plain, which was a major project by the government to "improve their life conditions" [16] (p. 273) in the 1960s. Both elements show their dedication to their traditions and to the land.

Based on participant observation in the balanced-stance between "observer" and "participant," informal interviews were implemented along with the above six categories, and specifically on festivals. The author collected demographic information from interviewees, including age, gender, occupation, family members, marital state, and tribal affiliation. The number of interviewees except for the preliminary survey was 153: 21 in Village B, 42 in Village M, 20 in Village Z, 70 in Village T. For open question interviews in Village T, interviewees were selected from the people who had their lives mainly in the community, such as housewives or someone with his/her occupation inside the community. They were selected from both genders and also from both the Amazigh and Arab families. However, the method used in this study is not a sample survey, so it was not intended to include all age groups. Although the targeted main informants were the facilitator and committees of the festival who were males in their 50s to 60s, the most informative interviewees about traditional customs were women accordingly, who are more likely to stay inside the village than men.

In this research, the author employs a hermeneutical approach following the methodology of history of religion as creative hermeneutics on religious data [17]. Interviews were recorded as audio data, and custom practices were recorded as video data. They were analyzed to identify repeated patterns of meanings and ways of thinking in order to achieve insight into participants' experiences and worldviews. In the process of participant observation, the author attended Mahrajān in Village T in July 2015, Ehtifēl in Village T 
and that in Village $Z$ in 2017, and pilgrimages to twenty sanctuaries in the suburbs, and conducted interviews about six other sanctuaries.

\section{Amazigh Culture and Overview of Village T}

Village $\mathrm{T}$ is known as one of the places where Amazigh language is still in use, while the number of Amazigh speakers is less than $1 \%$ of the population in Tunisia. Although their official religion is Sunni Islam, the customs of Village T are affected by the traditional Amazigh culture, whose traces can be dated back to prehistoric times. The existence of animistic beliefs found in rock paintings [18] or belief in numerous "local gods and lesser spirits" in the Phoenician colonial cities [19] (p. 35) probably have relevance to the current Amazigh culture. Stillman [18] stated that "nature worship" lasted to be the core of Amazigh religiosity into the modern era despite the official overlay of Islam. For instance, the ancient Amazighs frequently placed sacredness on rocks, mountains, caves, and springs, some of which still exist for their modern descendants.

Although they were impersonal forces, some of the spirits dwelling in these sanctuaries had names, like many of the jinn of later Amazigh folk beliefs [18]. Moreover, the tombs of Amazigh kings and ancestors were worshiped as sites of ancestral rituals that were closely linked to the wealth of the land. The rituals in which Amazighs predicted whether their wishes would come true by sleeping in their tombs have been practiced since ancient times [20] (IV: 174), [21] (pp. 46-48), [22]. As several ethnographies have reported, prayers to the dead (ancestors) accompanied by dream divination have been practiced until recently among the Amazigh tribes across North Africa and the Sahara [23] (p. 415), [24] (p. 412), [25] (pp. 61-63). This characteristic form of religiosity is thought to have continuity with the complex belief in jinn, ancestors, trees, caves, and saints, which is still practiced today in Village $\mathrm{T}$ functioning as fertility rituals. The sensitivity to place found in this village seems to be linked to the characteristic religiosity and natural landscape.

Southern Tunisia covers the Djeffara, an alluvial plain facing the Mediterranean Sea and stretching from Gabes to Tripoli, the Dahar plateau extending westward into the desert, and the Demmer mountain range, the eastern edge of a plateau with abyssal ledges that form a type of cliff that stretches from north to south. The mountainous terrain also includes gorges and meandering dry valleys pummeled by the heavy rains in winter, creating a varied landscape. In the seventh century, when the Arab tribes invaded the region, some Amazigh groups fled the coastline and took refuge in the mountainous area of Matmata, while other groups simply surrendered to the Arabs and assimilated with them. It was not only the conflict between two different types of production but also confrontations between two ethnic groups with their different backgrounds and lifestyles. Although the tribes called "Arabs" include Arabized Amazighs [26] and the actual distinction between the two would have become blurred, the conflicts between the Arabs and the Amazighs persist to this day. The elders in the neighboring village believe they are of "true Arab blood" and consider the "Berber" (Amazighs) as inferior [16] (p. 45).

In contrast, the independent spirit of the Amazighs, threatened by the invasion of the surrounding Arab tribes, was very pronounced, and many of them formed settlements on mountainous cliffs and peaks that were not easily accessible to invaders. Nevertheless, due to the scarcity of arable and grazing land, they had to accept a certain degree of subordination and negotiation with the surrounding Arab tribes for survival. Even so, the Amazigh tribes, proud of their "Berber" identity, resisted Arabization, Islamization, and the French occupation forces with remarkable vigor. As a result, they have been characterized as people with a strong spirit for local, political, social, and cultural independence [18].

Village $\mathrm{T}$ is located on top of a mountain at $480 \mathrm{~m}$ above sea level, $40 \mathrm{~km}$ southsouthwest of Gabes. According to the village narrative, the tribe initially lived in the extreme southern region of Tunisia, near the Libyan border, and settled in another mountain in this area approximately 2500 years ago. Then, their move to the present location occurred roughly 1500 years ago. The center of the village was a fortified settlement. However, the village was dispersed in the surrounding mountainous areas as there were inadequate 
water resources or suitable land for cultivation and grazing to support the population. According to Louis [27] (p. 37), there are two types of Amazigh settlements in the Demmer Mountains: (1) those that are concentrated and isolated, and; (2) those that are scattered under Arab patronage. In this regard, Village T includes both characteristics. Specifically, it is independent to maintain its autonomy from the surrounding forces while its economic base is supported by several sub-settlements that cultivate their land in the gorges of the hinterland.

Since its annual rainfall is $203 \mathrm{~mm}$ and the average annual temperature is $18.8^{\circ} \mathrm{C}$, it has a hot and semi-arid climate. In this dry and rocky land, the cultivation of fruit trees (mainly consisting of olives, figs, dates, and almonds) and the pasturage of goats have been practiced. As for its population, it is 913, according to the municipality's statistical data on 2014. However, as this number includes other neighboring villages (see Table 1), the population of Village $\mathrm{T}$ is probably half this figure (aside from temporary increases during the holidays). Moreover, as shown in this table, the village population appears to have decreased by an average of $36.6 \%$, which is worse than that of Delegation M (23.3\%).

Table 1. Population transition of Village T and Delegation M in Governorate of Gabes [28].

\begin{tabular}{cccc}
\hline & $\mathbf{2 0 0 4}$ & $\mathbf{2 0 1 4}$ & Balance (\%) \\
\hline Total population (Delegation M) & 5800 & 4444 & $-1356(23.3 \%)$ \\
Total population (Village T) & 1442 & 913 & $-529(36.6 \%)$ \\
Population, Male (Village T) & 714 & 390 & $-324(45.3 \%)$ \\
Population, Female (Village T) & 728 & 523 & $-205(28.1 \%)$ \\
Number of households (Village T) & 382 & 257 & $-125(32.7 \%)$ \\
Number of dwellings (Village T) & 691 & 501 & $-190(27.4 \%)$ \\
\hline
\end{tabular}

The inner village is divided into eight sections (sg. zīah, pl. zihēd), with Alaa Sirbred, the highest hill in the center on which the main mosque was built, and five adjacent sections: Tazet, Minaji, Mzana, Lmhaia, and Ghiren. A series of narrow paths stretch between these sections. The highest areas are where the oldest Amazigh families reside, and the other Amazigh families have built their dwellings around them. The new sections of Tounin and Slom are located at its western and eastern ends, respectively, and are where the majority of the non-Amazigh ("Arab") villagers have settled. Furthermore, the village is built in stages (from top to bottom), depending on when the clans were settled. Inside the village, there is an elementary school, a clinic, a post office, two grocery stores, three cafes, and two auberges for tourists. After the national highway had been constructed in 1992, tourists regularly visited the village to find the "real" life of an Amazigh village. However, since the Jasmine Revolution (2010-2011), very few tourists have visited or passed through the village due to the deterioration of public safety.

\section{Inside and Outside of Village Structure}

\subsection{Meaning of Cultural Realm}

Village T's cone shape is in line with Tuan's vertical value hierarchy [1] (pp. 36-38) in which the higher the level, the more central and holy it becomes. There are several concentric circles of trails around the village, with the summit at the center. The rows of houses that form circles along the paths are protected by high walls, which are designed to withstand attacks from the lower levels, thus highlighting the function of the village as a fortress in itself. In this way, Village $\mathrm{T}$ includes a center-periphery structure based on a vertical axis, where the more one moves to the center, the more he/she is protected from outside forces and the higher the elevation. As for the urban aspect of this settlement, namely, its concentration and stratification, the mosque built on top of the mountain adds the element of sanctity in the sky and strengthens its vertical structure after Islamization.

However, these understandings only focus on the interior of the village to determine its structure. By having a bird's-eye view of the village, it is possible to approach their experience of place more accurately. Precisely, Village T comprises a dichotomy of the 
concentrated and the sporadic suburban part-in other words: the acclimatized part, and the wild part, i.e., the area where the people have established their culture, and the area where they have not (see Figure 1). As for the cultural realm, it is composed of human-centered values, which are convenient and functional. For example, in the central community of Village $\mathrm{T}$, there are administrative offices, a school, and markets optimized for convenience and livable for humans. As Tuan [1] stated that the "people know better who they are and how they ought to behave when the area is humanly designed rather than nature's raw stage," the meaning of human existence is consolidated and purified in towns compared to sparse hamlets. This allows us to consider human beings, as opposed to nature in an abstract manner.

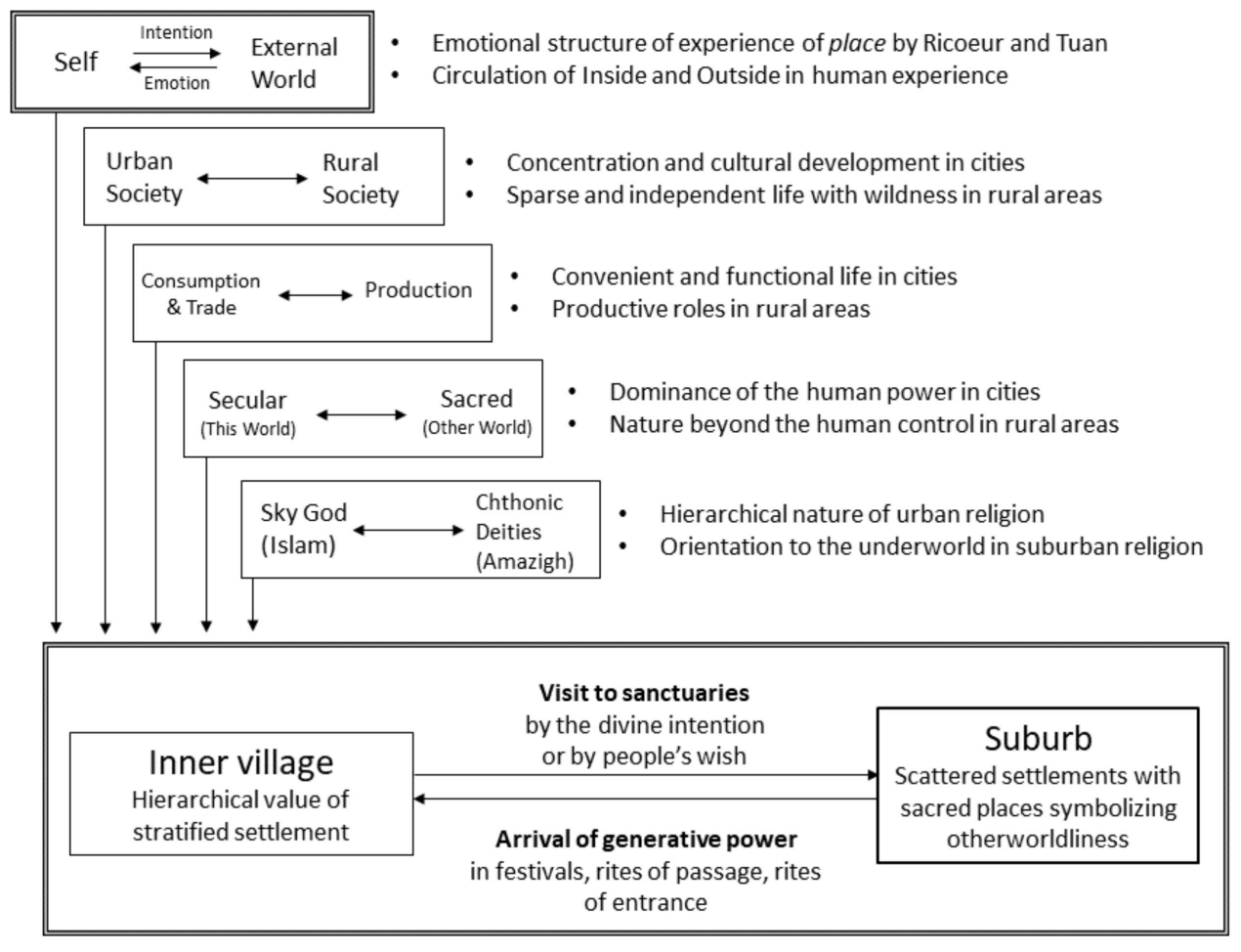

Figure 1. Analytical elements of inner and outer structure and the exchange model of Village T.

In general, various aspects of life, such as literature, art, trade, and other activities that are considered cultural, are developed in towns and cities. In terms of religion, when places are formed on the basis of utility, such as towns and cities, human values become more diverse and complex due to the concentration of population. Once a large, stable society is formed, it subsequently requires a complex cosmology with a unified and universal system, so that humans' cosmic duty can be more clearly grasped. Wheatley [29] (p. 225) pointed out that the establishment of ancient cities is not due to their political or economic superiority over their surroundings, but due to "an all-pervading religious context into which secular functions were subsumed" into their status as "ceremonial centers." According to Tuan [1] (p. 104), the act of building itself is "a religious act, the establishment of a world in the midst of primeval disorder." As towns, villages, and houses could not have been built without divine intentions, the construction of such aspects inevitably involves a cosmic allocation and rituals that ask for their support. However, as urbanization is also an expansion of human values, the tendency toward functionality permeates daily activities to the extent that it is far removed from the time of establishment. Moreover, if humans are not recognized for their roles in a unified world system, then their activities "seem arbitrary and may offend the gods or spirits of nature, unless they are perceived to have their roles and places in a coherent world system" [1] (p. 88). Therefore, the regular practice of rituals opens up towns and cities to sacredness by bringing temporary chaos, after which 
the "arbitrariness" of such locations is periodically broken down. As we will see later, the significance of Village T's festival is based on this very point.

\subsection{Precedence of Suburban Life}

In contrast, life in the suburbs was primitive, lacking the culture and convenience of the inner village. However, village life could not exist without the suburbs. In other words, people can live with low levels of cultural services, but they cannot live without production. The limited summit land available for cultivating fields and securing adequate pastureland was not large enough to feed them all. Consequently, the style of the village supported by production from the suburbs was established. In this sense, life in the suburbs was more independent than life in the central village.

Interestingly, the production sites were not clustered around the village like new territory, but they were sparsely scattered due to the arid climate of the region and the need to farm with such limited rainfall. They dug trenches to collect water from the hills and stored the winter rainfall underground for domestic and agricultural use. Moreover, they built terraces with weirs in the valleys of the hills to prevent water from flowing out of the soil, and cultivated olives, almonds, figs, and other fruit trees as well as drought-resistant grains. In such climatic and topographical conditions, the population that could be fed by their production patterns was limited. Thus, suburban settlements had to be relatively small. In this regard, the smallest settlements, some of which included only one family, were scattered around the $15 \mathrm{~km}$ perimeter of the village.

However, the suburbs and the central village have become one and the same unit of production, and each clan in the village has its own land in the village and that in the suburbs. In general, each family also has a house in the village, even though they work in the fields outside of the village. Those in the family who must live in the village, those who need education, and those who require medical care remain in the village, while those who can work on the farm live in the suburbs. They often move around with their livestock for a day or even several days. For them, the village is a place to interact with other regions of the human world, while the suburbs are places to interact with the things that bring them production. In the religious sense, what brings about life is the sacred. There also remains a certain sensitivity to an archaic sanctity that has a different vector from the Islamic sanctity toward the sky. For example, a former township chief stated, "There are saints (referring to the saint complexes and its ritual sites) in the village, but the good saints are in the countryside" (Interviewed on 7/15/2015). Moreover, when the women of the village are unable to have children or find a marriage partner (i.e., when they have production problems), they do not visit the mosque. Instead, they visit a saint in the suburbs and appeal to her/him to restore their own stagnant productivity. In other instances, when they fall into situations that are not proper, such as illness or economic malaise, they similarly appeal to the suburban saints to make their wishes granted [27] (pp. 326-328), [16] (pp. 84-86, p. 122), [30]. In sum, while accepting urban religions, such as Islam, as doctrine and ethics, their existential mindset is toward the spirits of the wilderness.

When comparing the towns and suburbs, the suburbs are clearly the ones that are historically and ontologically ahead in terms of the people's lives. The suburbs, more openly exposed to nature, are an extension of the lifestyle in the wilderness that their ancestors lived as nomads. Additionally, in the town, human meaning is fixed in terms of economics, politics, education, and religion as a conceptual understanding, whereas in the suburbs, human meaning is sensed in contact with nature as something that is unique to each case, as an experience. Nevertheless, in terms of culture and "wildness," suburban life is not completely wild or, as Tuan [1] (p. 102) stated, "those who live in the suburbs also live in the human realm."

Finally, compared to the towns, the suburbs are exposed to an ever-changing wildness, and the people's control is much weaker. However, they make their lives easier by modifying the environment and devising new ways to live. For example, the hill valleys are filled in, the waterways are built to collect rain, plants are grown, and the people dig 
holes in cliffs to live. In this sense, there is a contrast between the acculturated and wild parts, even in the suburbs. This untamed essence is represented as spirits, nature, and the human ancestors who have been involved in it, i.e., the saints.

\subsection{Wildness in the Suburbs}

As Crapanzano [31] (pp. 16-17) remarked, the belief in saints is expressed in the form of a complex veneration in which various elements, such as spirits, natural objects, land, and ancestors, are symbolically linked. In Village T, it is the belief in trees bringing fruitfulness and caves in which the underground world and the source of the fruitfulness manifest. Among the fruit trees grown in the suburbs, the people of Village $T$ have particular olive trees with the power (baraka) to grant wishes such as the "tree of the spirits" or the "tree of the saints" [30].

While sacred trees in the world are symbols of a ladder in the sky or a pillar extending from the underworld to heaven [32] (p. 169), [33] (pp. 298-300), in this region, sacred trees are often worshiped together with caves and mountains. Hence, in their symbolism, such trees are represented as a link between humans on the ground and the spirits underground. In addition, olives are not shaped toward heaven but instead growing from underground and covering the earthly world. In southern Tunisia, olive trees are traditionally not trimmed, and they are grown in their natural form, i.e., the tips of the branches do not grow upward but hang down to the ground. The shape of the tree is that of a trunk rising from underground, spreading its branches above the ground, and then returning to the underground world as the olives drop, which is an analogy of human life. These revered trees also serve to protect the people by blocking the sunlight from the sky. From these aspects, it can be said that the spirits, i.e., the inhabitants of the sacred trees, are manifested in the North African world as chthonic beings appearing in springs and caves rather than in the sky [34] (pp. 262-301, [25] (pp. 16-17), [35] (pp. 194-197), [30]. Brett and Fentress [19] (p. 35) stated, based on Herodotus and Pomponius Mela's descriptions of ancient North African reverence for the dead, that ancient Amazigh tribes viewed spirits as ancestral deities and thus, "the funerary elements are mixed with fairly clear references to fertility." Additionally, the "other world," where ancestors and spirits reside and from which all life is brought, is thought to be connected to the human world through "gates" such as caves and trees. In this regard, people communicate with them by sleeping in spirit caves, near ancestral tombs, and under spirit trees by which these spiritual beings "ensure human fertility" to them. The same is true when there are problems with health, job, or personal relations. In such cases, visiting a cave or a tree brings people back to the "right" state of being, thus giving them strength and a feeling of complete renewal. In these customs, it is clear that the earth and the underground world are more represented than the sky as a source of power (e.g., blessings and curses) and as "other worlds" where life comes and eventually returns.

In addition to the above, what is noteworthy is that cave-dwelling is a traditional custom in this region. In the Demmer Mountains, including Village T, numerous Amazigh and Arab tribes have built cave dwellings suitable for both mountainous and desert areas [27] (pp. 227-244). In the case of Village T, the majority of the caves have been dug horizontally into the strata on the sides of the mountains or hills, with entrances that shut out the outside, leading to courtyards from which multiple rooms are carved in a radial pattern. While the structures built in the desert above ground are exposed to strong sunlight and cold nights, the cave dwellings carved into the edges of hills guarantee a comfortable temperature all year round. In fact, even the livestock are given shelter in the caves. Moreover, as the isothermal temperature is suitable for storing crops, the harvested olives and grains are stored in these caves throughout the year.

For the people, the underworld is not only a distant source of blessings, but it is also a close place that protects their lives. Similar to caves, large trees are the entrance to the underworld, which provide them rest under their shade, nurture them through their fruits, and protect them by baraka. In the anecdotes of Village $T$ related to the 
olive-saint sanctuaries, incidents of saints or the spirits of trees protecting people from snakes, foreign enemies, and other dangers are often mentioned. For example, in Onm Chemlali, a tree saint (spirit) protected a man from having his gun taken away by the cavalry of the occupying French Army (Interviewed on 5/17/2017), while in Chaabet Aisa, a stranger who cut down an olive tree without permission was tied up with invisible fetters (interviewed on 5/16/2017). Moreover, in Camoul Brel, spirits protected the pilgrims from snakes (interviewed on $7 / 25 / 2015$ ). Interestingly, it is not only the humans who are protected by the spirits but also the wild animals that live around them. For instance, in Onm Ilgār, a man who hunted rabbits was punished (interviewed on 7/24/2015), while in Onm Chemlali, the rabbits shot with guns came back to life (interviewed on 5/17/2017). These representations reveal that the trees and caves share the same qualities: they are a gateway to the other world; they are a source of life; they have the Earth-motherly characteristic of protecting and nurturing creatures from the harsh environment. The people's veneration of the mountain can be understood in a similar point. As Camps [35] (p. 196) stated, "the worship of the mountain, or on the mountain ... must be related to the constant veneration for the caves." The mountains of the area have two signs of accident topographique [35] (p. 194): a raised earth and a hole in the ground. Thus, in the Amazigh's experience of place, they perceive that the mountains not only lead to heaven but also to the underground, where the spirits reside.

This contrast between the village and suburbs not only characterizes the production of Village T but also seems central to the people's experience of place. To understand their experience, it is important first to provide an overview of the quality of traditional festivals in general, agricultural festivals in southern Tunisia, and then discuss the festive process of the most recent festival: the Mahrajān.

\section{Festivals in Tunisia and the Festive Quality}

In Tunisia, besides the Islamic and the Western calendar, the Julian solar calendar called 'Ajami, has been used to serve as the agricultural calendar [36] (p. 3), [24] (pp. 541-542), [37] (p. 159). The 'Ajami calendar has been involved in specific festivals and agricultural events throughout Tunisia that differ from the universal Islamic celebrations. The implementation of agricultural rituals, including prayers for rain, represents the general concern for the fertility of the land. However, with the industrialization of agriculture and the diversification of modern life, agricultural festivals have been disappearing in various areas. Today, such rituals have been replaced by a new type of festival called the "Mahrajān," which is a cultural event or local festival undertaken by the government to promote religion and tourism since the 1980s. However, this new festival in Village T represents the deep connection between olive cultivation, community preservation, and traditional folk beliefs that have been oppressed in the process of modernization [37] (p. 350) and recent Islamic fundamentalism. Specifically, the village's Mahrajān presents the multifaceted aspects of olive farming, olive oil processing, food culture, tourism, and symbolism, along with elements of the older local agricultural festivals.

Since the 1980s, the Tunisian government has been implementing policies to revitalize and utilize these festivals as cultural and tourism resources to counter Islamic fundamentalism and restore cultural diversity [37] (pp. 9, 350), [38] (pp. 99, 118). Widely seen in North Africa and Arab countries, the Mahrajān festivals are usually celebrated in Tunisia with parades, music, dance, and fantasia (i.e., horsemanship performances). These components can also be found in numerous festivals throughout the world, including monotheistic, pantheistic, and even atheistic cultures.

In general, festivals serve an important social function and are overarching selfexpressions of society. They are also a ritual "consumption" of social wealth [39] (pp. 45-61) and an opportunity to activate traditionally inherited symbolic meanings [40] (p. 264). It is a chance to display the mythical meanings of communities that are usually hidden. In this regard, as the parades, music, palanquins, dances, riots, dramas, and games unfold, established ethics, and the normal values are overturned to a state of primordial chaos. 
This role reversal, the dramatized replay of myth, and the representation of a community, as a sacred cosmos, are made visible so that the meaning of human beings, the community, and the world (which cannot be reduced to usefulness) is experienced, i.e., the meaning of existence "itself." For example, the maypole, widely seen in European festivals until the 19th century in which people cerebrated the coming of spring and the revitalization of animals and plants, symbolizes the center of the world and an archetype of living things. Similarly, in Japan, the parade of divine palanquins and personages (performed by children and youth) is an archetypal pattern that replays the creation myth. In this process, the city is sanctified by the circulating gods, and it becomes a "world" with a sacred meaning.

Due to the nature of the city with a growing community, urban festivals can be easily incorporated with tourism. Expanded festivals are no longer limited to the residents of small communities, as they are becoming more entertaining and consumptive than participative. These festivals always have performers and audiences and have characteristics that are indivisible from tourism and exhibitions. Thus, although it does not deny the significance of the festival itself, by holding the Mahrajān for visitors, it may hide its "festive quality." Kerenyi [41] (p. 53) defined this quality as being "a thing on its own, never to be confused with anything else. It can be confidently distinguished from all other feelings and is itself an absolute distinguishing mark." This also indicates that the quality is not subordinate to any purpose other than the realization of the act itself, i.e., the festival is accomplished performatively.

Finally, tourism and cultural preservation can be the motivation for a festival, but they cannot be the goal for the participating people at the level of experience. In addition, the success of a festival can neither be measured by the number of tourists nor the income that the village receives; it can be measured through the realization of the festive quality. This quality should allow the participants to experience a transient world away from their secular daily lives. In other words, if this event is expressed entirely in terms of the number of tourists and the traditional culture that is displayed, then it has lost its festive quality. Therefore, the following section explores the traditional festivals of southern Tunisia and examines such quality reflected in their rich symbolic systems.

\section{Traditional Agricultural Rituals in Southern Tunisia}

Because of the French occupation during which local festivals were prohibited and the rural development after the independence in 1956, many traditional rituals and festivals became inactive. According to the village elders, until the mid-20th century, the villages held numerous festivals. The following sub-sections cover various festivals, some of which are no longer held in Village $\mathrm{T}$ but still held in other villages and some that are held in Village T today. All of these festivals are closely linked to local agriculture, which, as stated earlier, is the main source of livelihood in the villages.

\subsection{Jumal 'Āshūrā'}

As the 10th day of Muharram has been associated with the indigenous traditional customs and rituals of each region [37] (p. 311), in Village T, it was called "Jumal 'Āshūrā'" or "Camel 'Āshūrā'" as a day of thanksgiving for the harvest and an opportunity for the encounter while it has been lost several decades back. Specifically, on the day of the festival, figures of a camel were created out of olive wood and cloth, after which young men acted as the camels and visited neighbors. Subsequently, the ritual fighting of the camels was performed in the square called braka. It was an occasion for young unmarried men to be formally presented in front of unmarried women. Symbolically, a camel, which is an essential animal for agriculture and transport, is represented by the doll in this festival that distributes the fruits and happiness associated with olive trees throughout the village. It gives vitality to the community as a whole and to the individuals in particular. As for the ritual fighting of the camels in the village square, it is thought to stimulate the productive forces of nature as well as the encounters between the young men and women. 
Regarding other events in the Jumal 'Āshūrā', each house in the village prepared 'asīdah with olive oil. Then, the men at the festival ate the 'asĩdah and decided whose was the best. In other instances, the tradition of unmarried young women visiting the saints in the mountains still exists in the neighboring Village M, while in Village Z, the people still offer bukhōr to the olive tree closest to each house.

\subsection{Onmok Tambo}

The ritual of Onmok Tambo in the autumn or winter, before or during the olive harvest, is a variation of the rain-making rituals prevalent in North African countries given various names [42] (p. 117), [27] (p. 323), [43] (p. 241), [44] (p. 522). Abu-Zahra [44] explained that the song of Onmok Tambo is generally performed by young girls and single women (e.g., widows and divorcées). In this song, Onmok Tambo refers to a doll, typically made of a large ladle crossed with a loom handle and adorned with clothes like a bride. The women carrying the doll (see Figure 2), accompanied by their children, go around the fields and houses singing the song of Onmok Tambo and zaghārìd (ululation). At that time, the holder of the doll accepts wheat or barley from the villagers and wraps them in the doll's costume, while the women sprinkle water on the doll.

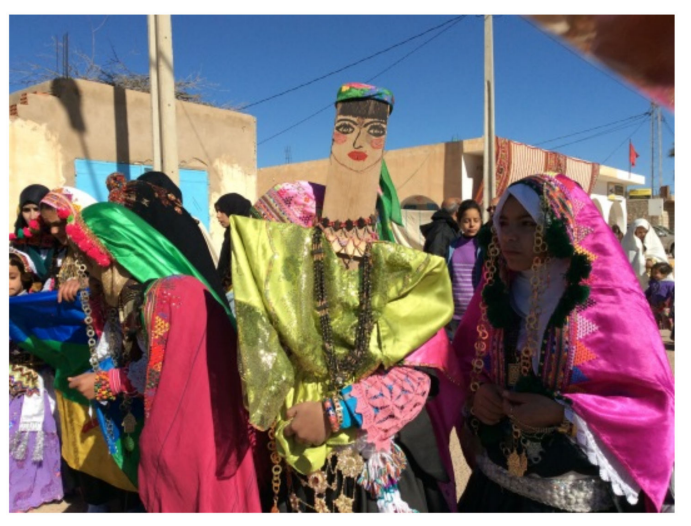

Figure 2. The doll of Onmok Tambo in Village Z.

This festival no longer exists in Village $T$ while it was previously held in the winter when there was a lack of rain. It is still held in mid-December in Village Z. In either case, a doll made of olive branches is brought to a house where there are unmarried young women. When the doll knocks on the door, a family member pours water on the doll and the earth. The next morning, the women serve the men 'asidah without olive oil, which is coarse and difficult to eat. When the men become hesitant, the women splash water on them. Symbolically, when eaten without olive oil, the food represents sexually inactive old women and dry land [44] (pp. 522-524), while the ceremonial act of pouring water on the doll and the ground is based on the similarity between such women and the land. Camps [35] (p. 197) pointed out that the purpose of this act is to cause water to fall from the sky, while the sexual symbolism is to increase the fertility of dry land. As in the Jumal 'Āshürā', there is a structure in which external sanctity is brought into the village through the parade of a female figure made of olive wood, thus symbolizing the earth. The Onmok Tambo further emphasizes the symbolic linkage between the fertility of women and that of the earth through the act of pouring water on the doll and making humans (in this case, women) engage in bringing water to the land.

\subsection{Ehtifēl}

The Ehtifēl is a new year's festival of the 'Ajami calendar around 14-15 January in the Gregorian calendar. Previously, it was celebrated by each clan instead of one event for the entire village. The larger clans had all of their female members gather at the braka to enjoy the horse rides and watch the bands from Douz or Gabes perform. Meanwhile, the families 
from various clans visited the olive groves and offered sacrifices of sheep to the sacred olive tree (olive saint complex), made couscous under the tree, and enjoyed music and hadra all night long. At that time, the Ehtifēl was more like a series of individual rituals and ceremonies. Today, in many homes, weddings and circumcisions are performed during this festival.

On the day of (or the day before) the Ehtifēl, the caretakers (khadem) of the sanctuary offer mulukhiya as a symbol of a full life, a good harvest to the ancient olive oil mill in a cave called "Onml Ma'asla" ("Mother Mill"), located $5 \mathrm{~km}$ from the central village. Their purpose is to wish for a good harvest and success for the Ehtifēl of the year (see Figure 3). According to K (60 s male), who is the khadem of Onml Ma'asla, the family of the khadem has the authority to prepare the soup. The same soup is eaten by his family on the same day as the communal fest with Onml Ma'asla. K has offered mulukhiya for the success of the festival every year. However, once he neglected to do so, and the flag at the entrance of the village was torn in half, and the Ehtifēl at that time failed. In this case, this ceremonial ritual represents the ontological precedence of the sanctity of the outside over that of the inside, which is similar to that of Village T's Mahrajān.

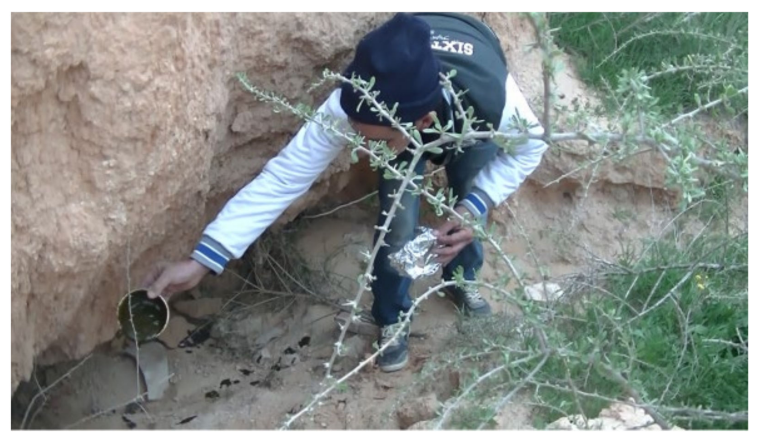

Figure 3. Khadem offering mulukhiya to Onml Ma'asla.

Since 2015, the Ehtifēl in Village T has been transformed into an expanded festival, for the purpose of integrating traditions as well as sharing presentations, such as children's processions, traditional foods, and costumes, to both residents and visitors. However, many of the residents do not agree with the festival committee's policy of utilizing traditional culture as a tourism resource. In fact, the villagers strongly believe that the current Ehtifēl is simply presenting a "fun show" for the guests from the cities, rather than focusing on the villagers' participation. Despite such criticism, this festival offers an opportunity for people from the suburbs to come to the village to celebrate the harvest, the new year, and to pray for rain as tasks for the entire community. This festival also provides people with a sense of communal reality and the ties between suburban and village life in a more visible way, which are bound together by agriculture and pastoralism.

\subsection{Pilgrimage to the Saints}

As mentioned earlier, North Africans have accepted the veneration of saints in connection with pre-Islamic symbols such as spirits, trees, and caves. Although the merging of the veneration of natural objects and saints is not characteristic to Village $\mathrm{T}$, what is distinctive is that this combined veneration includes the olive tree. In fact, the villagers see the power (baraka) of saints and spirits in nearly 30 sacred olive trees and visit them frequently. These saint complexes are not located in the village but in the mountains and the olive groves in the suburbs. The procedure of the pilgrimage is standardized: the offering of incense, bsisa (a sweet made of olive oil, sugar, and grains), and candles and lanterns, in addition to sacrificing animals and eating couscous with the offered meat. Sometimes they spend the night under the tree and dream about the oracles of the saints. Wishes for fertility, such as marriage, matrimony, and childbirth, are the main concern, as well as for recovery from illnesses, unemployment, and other general ailments. There is no fixed schedule for 
visitation, and when the people have a problem, they simply bring their respective animals to the shrine and make a vow/wish. If their wish is granted, then they revisit the shrine to make the promised offering [30].

It is important to note that the olive saint complexes serve as the guardian deities of the clans in the area and have a special connection with the caretakers that manage the sacred places. Among them, those who are specially linked to the holy olive trees are not only revered as being protected by the spirits and having sacred powers, but they are also eventually absorbed into the saint complex. Meanwhile, the clans that live on the land perform moussem (i.e., a festival for a saint) on certain days, although visits on other days and visits by non-clan members are freely allowed. In this case, their veneration of the saints at the olive saint complex on the outer periphery of the village differs from the general North African veneration of the saints at the mausoleums of saints inside towns, thus highlighting the experience of place of horizontal move from the inside to outside and vice versa. It can also be understood as leaving the human realm to engage with the world beyond the reach of human will and receiving the life force from the latter.

\section{Mahrajān in Village T}

\subsection{Preparation for the Festival}

The government of Gabes has been promoting and supporting a grand festival (Mahrajān kbir) involving five Amazigh villages. However, the local Mahrajān held in Village T (without government support) is relatively small in size, budget, and the number of participants. In addition, although the Mahrajāns held by the governorate include traditional or regional features, such as ceremonial displays or processing of agricultural products, they are conducted without the local communities' participation. Moreover, based on the government's strong initiative and support for the implementation of the Mahrajān kbir to promote tourism and attract audiences, the festivals have become "fun shows" (see Figure 4), which has made it difficult to understand the true nature of the festival. According to Turner [45] (pp. 131-165), festival participation is a total exchange that essentially involves roles and responsibilities for the operation of the cosmos and the community. The role of festivals is also different from that of ordinary life, and this sense of reality, this transition from the ordinary to the extraordinary, is the "the festive quality" [41] (pp. 49-70).
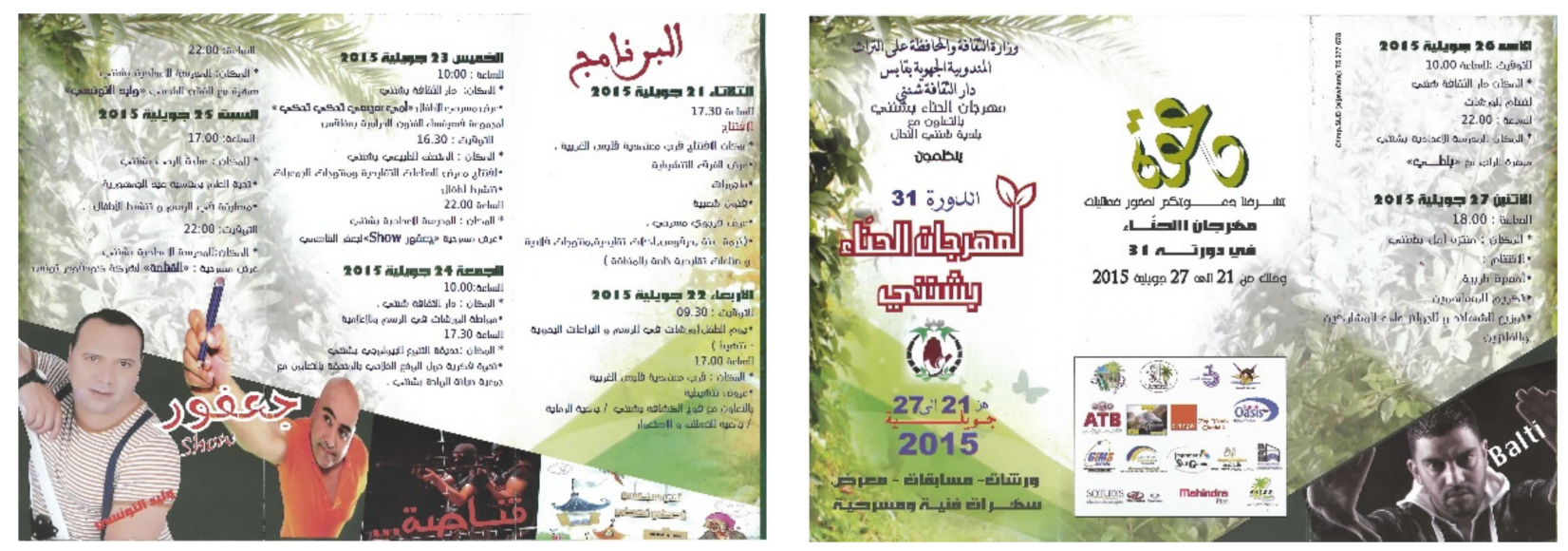

Figure 4. The program of Mahrajan kbir by the governorate of Gabes, with cinematic and theatrical performances as well as a rap concert.

In cultural events (e.g., music and film festivals) that are simply based on tourism and commercialism, participants are involved not in their roles and responsibilities but in their consumption and tastes, which are an extension of daily life. As a result, the festive quality of the events becomes unclear. On the contrary, the Mahrajān organized by Village 
$\mathrm{T}$ is relatively free from the bind of tourism, and it presents certain rituals and festive qualities as the core, instead of a series of "fun shows." However, many villages and towns in Tunisia still face pressure when considering which of these two approaches to undertake, a new vessel of their tradition or mass entertainment with standardized values.

According to the facilitator of the Mahrajān in Village T, who is in charge of negotiations with the Ministry of Culture and Heritage Preservation in the governorate of Gabes, while the central government supports the Mahrajān kbir, the Mahrajān in small villages do not receive such budgetary support. In some cases, this has made it extremely difficult for the villages to hold the event each year, with some forgoing the event. In fact, Village $T$ was the only village in the area to host the event in 2015, following a two-year gap.

Regarding other difficulties, the facilitator selected by the festival committee must spend considerable time consulting with the section officers and obtaining approval to hold a local festival on the scheduled date (July 26). The reason for such long negotiations between the government and the village is due to the uneasy history between the Amazighs and the Arabs represented by the central government. The villagers generally complain about government control, while the government officials tend to complain about the Amazigh villagers' stubbornness and resistance. Needless to say, the village's Mahrajān is accomplished through a delicate balance of power between the direction of the central government and the cultural independence of the Amazigh people.

For the Mahrajān in Village T, newly pressed olive oil made by a traditional stone mill, called $m a^{\prime} a s l a$, is essential. However, as ma'asla is unavailable in the village during the season, the facilitator is required to find ma'asla from the neighboring Village J. Recently, olives harvested in the winter are immediately pressed, while in earlier days, they were kept in storage for several years. However, following the tradition of the Mahrajān, dried olives harvested in the current season are prepared. From the traditional viewpoint, the older olives are considered better, as they are considered to have spiritual value and power as well as medicinal qualities. Additionally, as the main focus of this festival is to give thanks to the harvest, it is particularly important that the olives are from the current season's crop. Overall, approximately $30 \mathrm{~kg}$ of dried, black olives from the latest harvest is ground for half an hour and mixed with water to create a paste. This paste is then placed in a flat colander, called shwami, after which the oil is pressed. This process takes about a day, and it is crucial that it occurs before the festival, as the "mother of the groom" (on the morning of the Mahrajān) must bake 40 large loaves of bread (alwajib) and pour freshly pressed olive oil (oudhi) on them. The quantity of the loaves must be in multiples of 10 .

Needless to say, the facilitator in this festival seems to have a broad range of tasks. The major activities include but are not limited to: preparing old olive fruits, arranging for a stone mill, finding animals to run the mill, hiring musicians, building the palanquin, finding camels to carry the palanquin (see Figure 5), and selecting villagers to play the role of the Mahrajān's "brides" and attendants.

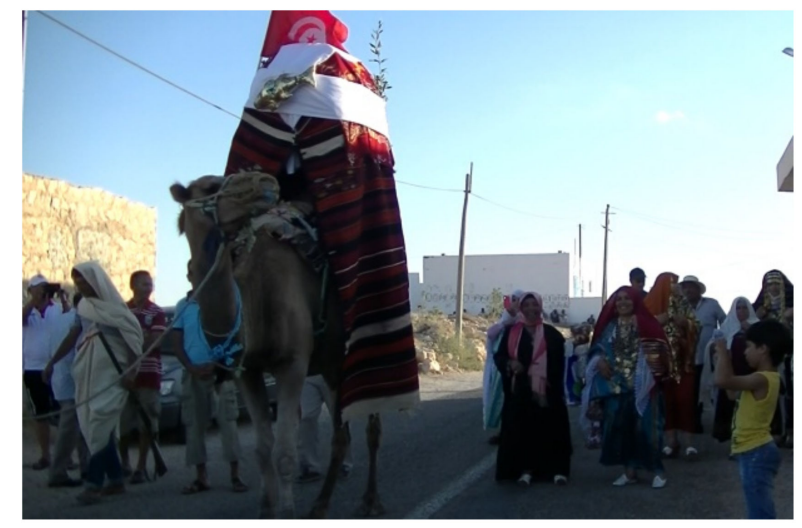

Figure 5. The departure of the palanquin. 


\subsection{Process of the Festival}

When the festival begins around 6:00 p.m., people gather in front of the office of the agricultural non-governmental organization (NGO), which is considered the "groom's house" (see Figure 6). This office was chosen because many of the members of the festival committee, including the festival facilitator, belong to this NGO. This area also serves as the new center of the village, which includes the post office, the clinic, and the most popular café where the majority of the village's men frequently gather, instead of the old squares in more geographically central areas such as the braka in Mzana or the market in Ghiren.

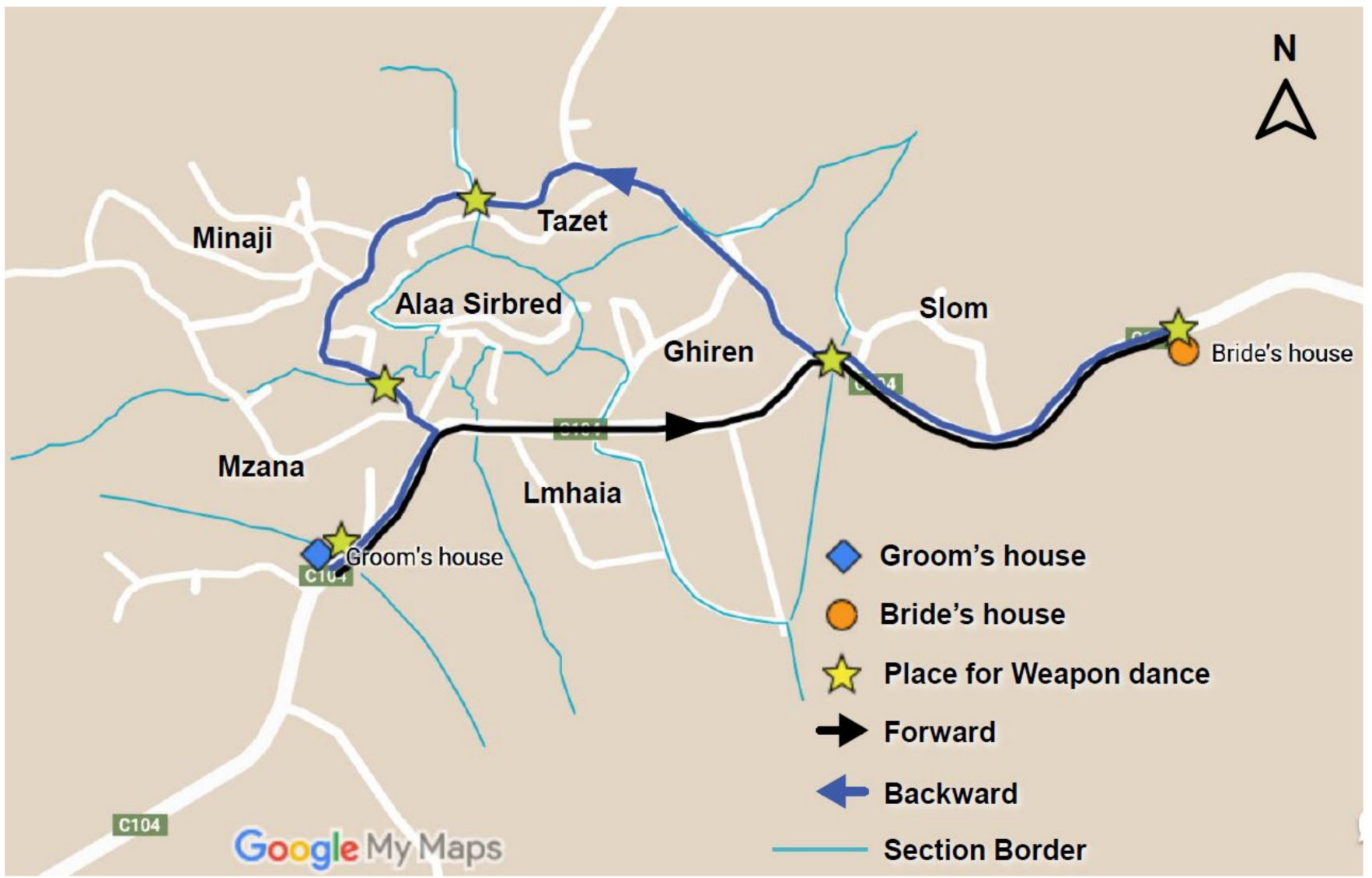

Figure 6. Map of the eight sections of Village $\mathrm{T}$ and the parade route.

At the gathering at the NGO office, a group of four "black" musicians from the village plays music with a drum (tabbāla) and an oboe (zurna). There, a small charcoal stove with incense is set up, and a palanquin ( $j a f f a$ ) on the back of a camel will eventually transport the "bride" of the festival from her home to the "groom's house." Red cloth, which completely covers the palanquin so that no one can see the "bride's" face, is decorated with fish amulets (to protect against bad things), the national flag, and olive branches, which are considered "indispensable for this Mahrajān."

Then, four or five young men, called hōli, carrying double-barreled rifles and dressed in white woolen cloth also called hōli, serve as "ministers" of the "sultan" and "sultana," i.e., as representatives of both families in their "wedding ceremony." The female members of the "groom's family," wearing the traditional melia, emerge from the house, and the procession begins. Meanwhile, the loaves of bread baked in the morning are placed in baskets and carried by two unmarried young women on the "bride's" side as a gift from the groom's family to the bride, exactly as it is done in a wedding procession. Young women are eager to play this role because it is considered to bring them good fortune and marriage in the near future. 
On the way to the "bride's house," located on the edge of the village, the parade is led by the musicians, an empty palanquin, the male roles, and other villagers (men and children), while the female roles sing a traditional song and wish for a good harvest. After the non-stop, slow procession, they arrive in front of the "bride's house," and the women enter with loud zaghāridd. Inside the house, the bread prepared by the "groom's" women is served, and a ritual communal meal is held while the men wait outside with the musicians and spectators. It is important to note that the "bride" is not allowed to touch the bread until her "mother-in-law" starts eating first. It is then eaten by all of the members of both families and her friends. In this situation, eating the bread also symbolizes good luck for the upcoming "marriage."

With her face covered by thin red cloth, the "bride" is escorted by a "black" woman called tēbet hennāna (Henna's agent). Her "black" color shuns evil spirits, while the status of the unmarried young women symbolizes their innocence and fragility in the presence of such spirits. Then, carrying his rifle (magroun), the "brother of the bride" in white $h \bar{o} l \bar{l}$, appears. The "bride" and the other women of the family are covered by his white cloth, after which they perform the ritual of confirmation with strong zaghārīd. When the confirmation is complete, the "brother" dons the hōli again, goes outside, and points the gun at the "bride," who plugs her fingers into the two barrels. As explained by the villagers, this act symbolizes the deflowering that takes place on the first night. If the bride has been previously married, then this act will not occur.

Once outside, they prepare the "bride" to sit in the palanquin, which is tightly covered and sewn by the camel handler. At that time, the "bride," the tēbet hennāna, the other women, and the camel bearer are all covered with white cloth. From the "bride's house," many women from the "bride's" side join the parade, and the tēbet hennāna carries a small brazier (kanoun) for the fumigation with incense (bkhor). Following the standing of the camel with the palanquin, the hōlis and other men set off fireworks (instead of ceremonial gunfire) and perform a dance of the weapons, called meiyāza, to music at the "bride's" house. In this dance, two men putting rifles on their shoulders or on the top of their heads facing each other circle around in small steps, reading each other's movements and suddenly holding their guns up to compete for their nimbleness. The weapon dances are performed in five locations on the way to the "groom's house." Overall, the procession passes through seven sections in a circle surrounding the central Alaa Sirbred, the highest point in the village. It is important to note that four of the stopping points, including the "groom's" house, are at the borders of these sections, while the other point at the "bride's house" is on the boundary of the village. In this regard, the villagers explained that the route and the locations of the dances are selected to cover all of the sections in the area, thus highlighting the nature of this Mahrajān.

When the party arrives at the "groom's house" at sunset, the camel handler cuts the thread on the cover of the palanquin and unfolds the hōli to hide the "bride" as she leaves the palanquin. Having prepared herself under the cloth, she reappears, surrounded by the sounds of zaghārid, and gestures with her finger to fill the gun of the "man of the bride's family." Then, the tēbet hennāna carries a bag called the koffa for the "bride," which contains water, almonds, perfume, sweets, bread, and olive oil. Those are overlapping with the contents of a trousseau at a traditional wedding [46] (p. 97).

Subsequently, the "bride" is greeted by the "groom's mother," who washes the right foot of her "daughter-in-law" before entering the gate. The rifle pointed at the "bride" is then handed over to the man on the "groom's side," who escorts her inside with the gesture. At this point, only the women and hōli are allowed to enter the "groom's house." After her entrance to the room, the gate, formerly closed, is opened for the male members of the procession. Next, they perform a weapon dance in the yard of the house to the women's zaghärìd and music, after which the dance transforms into conventional Tunisian folk dance found in a typical wedding party, and that includes all of the participants and visitors. After one hour of frenzied dancing, the music stops, and the Mahrajān ends. 


\section{Discussion: Symbolism in the Mahrajān}

\subsection{Succession of Agricultural and Marriage Rituals}

Village T, like many of the Mahrajān in Tunisia, has adopted a wedding exhibition into its festival to attract tourists because it is the most exhibitionistic and spectacular event among their traditions. Accordingly, it is essential to provide an overview of traditional wedding ceremony in the village since it is a prototype of the Mahrajān) and analyze their symbolic meanings. For example, the second day of a traditional wedding, i.e., the day when the groom's side goes to the bride's side to bring the bride to their location, or the "day of jahfa (palanquin)," is the basis for the Mahrajān [46] (pp. 97, 102).

In general, traditional weddings are never isolated from the rhythms of agrarian life. For instance, during the ceremony, most meals consist of subsistence crops, including bread (alwajib), freshly pressed olive oil, olive fruits, and traditional sweets such as bsisa (cereal paste). Today's ritual of pressing olive oil for the Mahrajān follows this tradition, as it emphasizes the harvest of the year. At the bride's house during the wedding ceremony, an older woman confirms the bride's virginity, and a member of the bride's family puts some olive oil in his/her mouth and spits it six times on the bride's head. This action is based on sympathetic imagery to stimulate the power of olive oil to purify and urge the couple to make their first relationship "as smooth as olive oil" [46] (p. 100). Meanwhile, the groom holds a ceremonial scepter (aamout) made of olive wood, decorated with pompoms and tassels, as a symbol of masculinity. This scepter is also inscribed with the words of the Quran, the date of the ceremony, and the groom's name. The groom must carry it with him for the entire ceremony and bring it to the bedroom to protect him from evil spirits and to complete the first conjunction.

Many symbols are also depicted on the bride's wedding dress, among which the most significant is the flowering olive tree. In southern Tunisia, the flowering olive tree is referred to as a "bride" (larousa), and the appearance of its beautiful blooms indicates abundant harvests and evokes a religious sensitivity to find the resemblance between the trees and the people. Similar to many religious myths around the world that show the universal connection between women and the productivity of the earth [11] (pp. 138-147), the symbolic use of plants and gestures in the wedding rituals of Village $\mathrm{T}$ are practiced with an agricultural sensibility, based on the similarity between the fertility of the land and that of humans. Additionally, weddings, as well as the Jumal'Āshūrā' are a rare opportunity for open communication between young men and women in Village T [46] (p. 99), where chastity is of utmost importance (at least under Islamization). In fact, as the inclusion of this function in the Mahrajān, it has become an important meeting opportunity for the younger generation in the village with city dwellers who return to their relatives for their parents' homecoming.

Furthermore, it is necessary to consider the reasons behind the choice of elements of a traditional wedding in the Mahrajān, as a cultural resource for tourists. The imitation of traditional weddings with agrarian symbols is based on the continuity between fertility festivals and weddings and on the importance of weddings themselves in the community. Especially in this patrilocal society, the arrival of a wife means the intrusion of an outsider into the house of a groom's family, which symbolizes the arrival of an external productive force. The period between the marriage rites is also a transitional phase from her parent's house to her husband's house, i.e., "the marginal state" [47] (pp. 124-136) from the predetermined status (daughter) to the new status (bride). In such a situation, the norms of the world become ambiguous, and the community becomes chaotic. Accordingly, the many charms and behaviors used in wedding ceremonies, such as incense, the red veil, the washing of the right foot, and the accompaniment of tébet hennāna against evil are meant to prevent "accidents" in such ambiguous and dangerous situations. Such an ambiguous transitional state is also necessary for creating the birth of the next life and symbolizing the primordial chaos for the creation of the cosmos, which is the most important myth and archetype of human behavior. Therefore, human generative behavior, including marriage rituals, is regarded as a dramatic imitation of cosmic creation and the cosmic marriage 
of the goddess and the god [11] (p. 145). In other words, the Mahrajān procession is not only a reenactment of the traditional marriage ritual and an exhibition of the traditional customs for tourists, but it also fulfills the function of replaying the primordial creation that the marriage ritual basically involves.

\subsection{Marginality in the Parade}

Concerning the time flow of the festival, Leach [47] (pp. 132-136) presented four phases of festivals: (1) the rite of sacralization or separation, i.e., "the transition from the secular-profane world to the sacred world"; (2) the marginal state; (3) the rite of desacralization or aggregation, i.e., returning "back from the sacred world to the profane world" in which a person is "reborn" and the secular time starts anew; and (4) the normal secular life. Leach also discussed these four phases in terms of three types of ritual behavior: formality, masquerade, and role reversal. In this regard, the first and third phases reciprocate attitude with formality and masquerade, while the second phase is the period when the otherworldliness is realized in the festival, i.e., when the place of the village is transformed into a sacred world. The enclosed ritual process is also kept under careful and strict control by the tēbet hennāna or mistress of ceremonies in the "bride's house." Furthermore, we find formality at "the rite of sacralization or separation" where the rules hold importance until the departure of the bride. Additionally, during the weapon dances and when carrying the bride around in the palanquin, the village is in a state of marginality, i.e., the state of the otherworldly movement. Meanwhile, in the final dance at the "groom's house," we find a bacchanalian state in which their official status and the formal rules of orthodox life are "forgotten."

As for other aspects, transportation of the "bride" from her home to a new place and putting her in a marginal state brings a festive quality to this modern festival. In general, a transition is a common motif in festivals, and it is typified by role reversal. The act of undergoing the wedding itself expresses the transitional status of the bride, the families, and the community, while the weapon dances signify the transitional nature of the Mahrajān in the time and space between the sections. The dances at the boundaries of the sections explained as a way to involve the entire community in the festival, also symbolically activate the comings and goings at the boundaries and organically link the sections.

Moreover, the location of the "bride's house" on the edge of the central village emphasizes the dynamism of the center and periphery as well as the inside and the outside. The movement of the parade from the "groom's house" in the center to the "bride's house" on the edge of the village clearly represents the arrival of outside productive forces, as seen in the Jumal 'Āshūrā' and Onmok Tambo. Specifically, the villagers' acts of traveling to the edge of the village and welcoming "the bride" emphasize the transition and the arrival of external power which sanctifies the internal structure of the village by outside forces. Interestingly, the fact that the palanquin avoids the mosque at the top of the mountain indicates not only the inaccessibility due to the narrow paths, but also the festival is governed by the reality of the place which is different from the symbolism of Islam.

\subsection{Introducing Externalities}

Why do we need this type of interaction between the inside and the outside? Eliade [11] (p. 73) stated, "the cosmos is conceived as a living unity that is born, develops, and dies," and this notion must be understood from the "archaic" significance of vitality, as "life is the absolute reality, and, as such, it is sacred" [48] (p. 61). However, a living entity can never be a completely closed existence. It must take in substances from the outside environment into its body, and it must expel something from itself to the outside through eating and excretion, inhalation and exhalation, sexual intercourse, and birth and death. In addition, the structure in which something enters and leaves the entity is the essence of the organism. Otherwise, it would be unable to maintain its existence as an individual or as a species. 
The newly gathered olive branches and the newly pressed olive oil in the Mahrajān are symbols of life for the village, which depends on olive cultivation for its sustenance, and they literally give life as food to the people and to the community. This style of introducing vigorousness from the outside is also seen in cosmogonic rituals such as marriage and new construction. For instance, at the beginning of the marriage ceremony in the village, which used to last for approximately ten days, the ritual of "collecting firewood" is performed. Specifically, volunteer men from the village head into the wilderness to collect a dry plant, called rtem (Retama raetam), stay overnight, and return at dawn. All of the meals for the wedding celebration are then prepared with this wood [46] (p. 96). In another instance, when bringing in the large stones for the olive mill, the men take their families, neighbors, and musicians with them to the nearby mountains. In this case, it takes days to haul the megaliths and adequately deliver them to the olive mill in the village, where they are offered goats and bsisa. As this is a ritual of "entrance" rather than just a construction work, it includes not only powerful men but also well-dressed women and children [27] (p. 176). What today's Mahrajān and these older rituals show is their recognition of the reality that it is what comes from outside the village, or more simply, the outside world, that allows us to live, produce, be reborn, and give birth to another generation. In other words, it shows where and how the ontological roots of the inner life of Village T are located.

It is also worth noting that this event of "arrival" from the outside to the inside, which is realized in the Mahrajān, is complemented by a "visit" from the inside to the outside, which occurs around the same time. Like the pilgrimage to the ancient oil-pressing caves during the Ehtifēl and before and after the Mahrajān, families, including those returning from the city, often make pilgrimages to the olive saint complexes in the ancestral lands of the suburbs. Both the sanctification of a community by something brought from the outside and that of an individual by going out (as in a pilgrimage) is the way of exchange, i.e., the experience of the organic dynamism between a structure and its exterior. By regularly freeing the boundaries of the individual entity of a community, which is a basic nature of life (such as eating or breathing), the community and its members become more "alive." In this sense, the archaic dynamism of the sacred and the secular, or the outside and the inside, is experienced in the modern Mahrajān.

Similarly, Tuan [1] (pp. 113-115) provided the example of Pygmies (one of the simplest social structures), pointing out that for them, the religious space is not within the camp but in the surrounding forest. He also revealed that their primordial religious sensibility of "what they make and build is trifling compared with the circumambient and life-supporting forest" defines the spatial composition of their camp. In another example, the most ancient layer of Japanese mythology is based on raging terrestrial deities who are both a blessing and a danger to man (Kunitsukami). However, with the expansion of the human realm, such deities are exorcized and replaced by more harmonious and idealistic celestial deities (Amatsukami) [49].

Regarding the primordial sacred, it is often dispelled by classical religions as "evil gods" or "evil spirits" because, as Otto [13] (pp. 5-7, 25-30) stated at the beginning of his definition of the holy, the reality of the experience sui generis that the holy is beyond human intention has been superseded by the ethical value that the holy is for human beings. The danger of untamed sacredness and the avoidance of it can also be seen in Village T, where it is understood in the form of punishment for those who carelessly approach the olive saint. However, as Tuan [1] (p. 88) pointed out, it is too "arbitrary" to only engage with human-made objects because of the dangers. In addition, to lose the connection with the sacred, i.e., with the meaning that is not reduced to usefulness, is to render human life meaningless. In this regard, people have the dichotomy of always wanting to be near the sacred, despite knowing the dangers. In The Sacred and the Profane [11] (1959, p. 11), Eliade posited that such ambivalence of orientation to the sacred and the secular includes a dialectic form in which it is sublated by the experience of the appearance of the sacred.

Considering this in terms of place, when the life force is exhausted inside the community or when there is a need to start something new, people head outward from within 
and take in the significance that comes from a realm beyond human control. Meanwhile, within the village, they wait for the emergence of the otherworldliness, such as new life and new power for creation, which comes from the outside. For example, the doll of olives in the Onmok Tambo ritual, the camel of olives in the Jumal 'Āshūrā', and related symbols, such as olive branches, the bride, and the camel's palanquin in the Mahrajān, are used to visualize what is coming from the outside. As Tuan [1] (pp. 36-37) pointed out, "ritual occasions ... lift life above the ordinary and so force him to an awareness of life's value, including those manifest in space," and festivals are experienced as moments that reveal the difference between the inside and the outside embedded in everyday life. In this regard, the human realm regains its sacred meaning, while the untamed nature becomes a meaningful place for humans, i.e., a place where a new world of meaning is created.

\section{Conclusions}

This study critically examined Relph [2] and Tuan's [1] ideas on the experience of place and explored the human experience of the sacred place. It turned out that the basis of this idea is an understanding of the coincidence of emotion and intention in the reality of experience, and that human experience is made up of circulation of inside and outside, such as orientation toward the external world and influence from the outside on the internal will. The examination revealed that such experience resembles, in the sense of being far removed from volitional control, sui generis element of religious experience, i.e., the manifestation of the sacred. By interpreting the festival of the indigenous community according to these understandings, it was shown that the dichotomy of this world and the other world is experienced in modern events as a dynamism of inside and outside. More specifically, the three points of this investigation are summarized as follows.

First of all, the place they experience consisted of two opposing characteristics: (1) the interior of the village and the human realm and (2) the suburbs and the untamed nature outside. Environmental factors, such as agro-pastoralism suited to the climate and topography, and historical factors also influenced the experience of these two places. This contrast is represented in the two relations with "sacredness": (1) to bring the life force from the outside, and (2) to leave the inside community to visit the sanctuaries in the suburbs. Secondly, the current tourism-oriented Mahrajān in Village T represents the traditional structure of agricultural rituals in which arbitrariness is periodically broken down by introducing externalities into the inner human realm. This contrast between the inside and outside of the human realm implies general opposing attitudes: an orientation toward the useful, an avoidance of what is beyond the control of human power, and an orientation toward the sacred beyond the control, thus not reduced to the useful. These two ambivalent ontological orientations are reconciled by the experience of the festival, which is the realization of the sacred (hierophany). Finally, as the sacred manifests itself in the village, the useful meanings attached to individual places dissolve, and the village becomes a sacred place. In the Mahrajān, olive cultivation in the suburbs and the village is newly sanctified and renewed by the dynamism of the inside and the outside. In other words, that is when people realize the source of the new harvest and that of new lives, and they experience the essential meaning of generation and production. In sum, although the Mahrajān is a modern festival aimed at tourists, it could be understood as having the universal structure of traditional festivals, in which places are sanctified by otherworldly beings brought from the outside.

This study brought a hermeneutical perspective of religious studies into the theory of experience of place of cultural geography, which provides new insights into the consideration of the human experience of space. It proposes a different perspective to the existing discussion of social and cultural sustainability in the crises of modernization and transformation to which indigenous cultures are exposed: the importance of "experience" of the people involved. However, because this study focused on the experience of place of the members of the community, it was not possible to discuss the experience of place of tourists coming from outside. In order to understand this research more comprehensively, 
it is necessary to consider how the experiences of insiders can affect those from outside and vice versa, which remains an issue for future research.

Funding: The author acknowledges that this research is supported by the JST-JICA Science and Technology Research Partnership for Sustainable Development Project, Grant Number JPMJSA1506: Valorization of Bio-resources in Semi-Arid and Arid Land for Development, and by JSPS KAKENHI Grant Number JP19K12954: Veneration of Edible and Medicinal Plants and the Multilayered Cultural System of North Africa.

Institutional Review Board Statement: According to the Rule for the Ethical Review Board of the University of Tsukuba Involving Human, this study is exempted and does not require the approval of the institutional review board.

Informed Consent Statement: Informed consent was obtained from all subjects involved in the study.

Conflicts of Interest: The author declares no conflict of interest.

\section{References}

1. Tuan, Y.F. Space and Place: The Perspective of Experience; University of Minnesota Press: Minneapolis, MN, USA, 2018.

2. $\quad$ Relph, E. Place and Placelessness; Pion Limited: London, UK, 2008.

3. Jafari, J.; Pizam, A.; Przeclawski, K. A sociocultural study of tourism as a factor of change. Ann. Tour. Res. 1990, 17, 469-472. [CrossRef]

4. Greenwood, D. Culture by the Pound: An Anthropological Perspective on Tourism as Cultural Commoditization. In Tourists and Tourism: A Reader; Gmelch, S.B., Ed.; Waveland Press Inc.: Long Grove, IL, USA, 2004; pp. 157-169.

5. Yang, J.; Ryan, C.; Zhang, L. Social conflict in communities impacted by tourism. Tour. Manag. 2013, 35, 82-93. [CrossRef]

6. Seamon, D.; Sower, J. Place and Placelessness, Edward Relph. In Key Texts in Human Geography; Hubbard, P., Kitchen, R., Vallentine, G., Eds.; Sage: London, UK, 2008; pp. 43-51.

7. Husserl, E. Ideas: General Introduction to Pure Phenomenology (Ideen zu Einer Reinen Phänomenologie und Phänomenologischen Philosophie); Gibson, W.R.B., Ed.; The MacMillan Company: London, UK, 1931.

8. Marriot, M. Hindu Transactions: Diversity without dualism. In Transaction and Meaning: Directions in the Anthropology of Exchange and Symbolic Behavior; Kapferer, B., Ed.; Institute of the Study of Human Issues: Philadelphia, PA, USA, 1976; pp. 109-142.

9. Marriot, M.; Inden, R. Toward an ethnology of South Asian caste systems. In The New Wind: Changing Identities in South Asia; David, K., Ed.; Mouton Publishers: The Hague, The Netherlands, 1977; pp. 227-238.

10. Strathern, M. The Gender of the Gift: Problems with Women and Problems with Society in Melanesia; University of California Press: Berkeley, CA, USA, 1988.

11. Eliade, M. The Sacred and the Profane (Das Heilige und das Profane); Trask, W.R., Ed.; A Harvest Book: New York, NY, USA, 1959.

12. Ricoeur, P. Freedom and Nature: The Voluntary and the Involuntary (Le Volontaire et L'involontaire); Kohák, E.V., Ed.; Northwestern University Press: Evanston, IL, USA, 2007.

13. Otto, R. The Idea of the Holy (Das Heilige); Harvey, J.W., Ed.; Oxford University Press: London, UK, 1936.

14. Lévy-Bruhl, L. Les Fonctions Mentales Dans les Sociétés Inférieurs; Les Presses Universitaires de France: Paris, France, 1910.

15. Tambiah, S.J. Magic, Science, Religion, and the Scope of Rationality; Cambridge University Press: Cambridge, UK, 1990.

16. Kacem, B.H. The Cave-Dwellers of Matmata: Ritual and Economic Decision-Making in a Changing Community. Ph.D. Thesis, Department of Anthropology, Indiana University, Bloomington, IN, USA, 1977.

17. Eliade, M. History of Religions and a New Humanism. Hist. Relig. 1961, 1, 1-8. [CrossRef]

18. Stillman, N.A. Berber religion. In The Encyclopedia of Religion; Eliade, M., Adams, C.J., Kitagawa, J.M., Marty, M.E., McBrien, R.P., Needleman, J., Schimmel, A., Seltzer, R.M., Turner, V., Eds.; MacMillan Publishers Company: New York, NY, USA, 1987; Volume 2, pp. 109-111.

19. Brett, M.; Fentress, E. The Berbers; Blackwell Publishing: Malden, MA, USA, 1997.

20. Herodotus. The History of Herodotus; Macaulay, G.C., Ed.; MacMillan: London, UK, 1890.

21. Romer, F.E. Pomponius Mela's Description of the World; The University of Michigan Press: Ann Arbor, MI, USA, 1998.

22. Camps, G. Funerary monuments with attached chapels from the northern Sahara. Afr. Archaeol. Rev. 1986, 151-164. [CrossRef]

23. Duveyrier, H. Les Touareg du Nord; Challamel Ainé: Paris, France, 1864.

24. Doutte, E. Magie et Religion dans l'Afrique du Nord; Librairie d'Amérique et d'Orient: Paris, France, 1984.

25. Basset, H. Le Culte des Grottes au Maroc; Ancienne Maison Bastide-Jourdan: Alger, Algeria, 1920.

26. Louis, A. Contacts entre culture "Berbèr" et culture arabe dans le sud tunisien. In Proceedings of the First Congress on Mediterranean Studies of Arabo-Berber Influence; Galley, M., Ed.; Société Nationale d'Édition et de Diffusion: Alger, Algeria, 1973; pp. 394-405.

27. Louis, A. Tunisie du Sud: Ksars et Villages de Crêtes; Centre National de la Recherche Scientifique: Paris, France, 1975. 
28. République Tunisienne Ministère du Développement de l'Investissement et de la Coopération Internationale Office de Développement du Sud. Gouvernorat de Gabès en Chiffres 2014. Available online: http:/ /www.ods.nat.tn/upload/CHIFGABES.pdf (accessed on 15 March 2016).

29. Wheatley, P. The Pivot of the Four Quarters; Aldine Publishing Company: Chicago, IL, USA, 1971.

30. Kitagawa, T. Pilgrimage to old olive trees and saint veneration in North Africa. Int. J. Arts Hum. 2017, 5, $264-293$.

31. Crapanzano, V. Tuhami: Portrait of a Moroccan; University of Chicago Press: Chicago, IL, USA, 1980.

32. Smith, R. Lectures on the Religion of the Semites; D. Appleton and Company: New York, NY, USA, 1889.

33. Eliade, M. Patterns in Comparative Religion (Traité D'histoire des Religions); Sheed, R., Ed.; Sheed and Ward Inc.: New York, NY, USA, 1958.

34. Westermarck, E. Ritual and Belief in Morocco; Macmillan and Co. Ltd.: London, UK, 1926; Volume I.

35. Camps, G. Berbèrs: Aux Marges de l'Histoir; Éditions des Hespérides: Paris, France, 1980.

36. Anonymous. L'anne agricole chez les indigenes de l'extrême-Sud Tunisien. Rev. Tunis. 1910, 79, 3-6.

37. Takaki, K. Kita-Africa No Seijya Shinkō; Tosui Shobo, Publishers \& Co. Ltd.: Tokyo, Japan, 2000.

38. Venema, B. Les Khroumirs: Changements Politiques et Religieux dans la Période 1850-1987; VU University Press: Amsterdam, The Netherlands, 1990.

39. Bataille, G. The Accursed Share: An Essay on General Economy (La Part Maudite); Hurley, R., Ed.; Zone Books: New York, NY, USA, 1988; Volume 1.

40. Marquet, L.; Spera, E.; Kuramochi, F.; Russ, J.M. Yōroppa No Syukusai; Kawade Shobo Shinsha Publishers: Tokyo, Japan, 1996.

41. Kerenyi, C. The Religion of the Greeks and Romans (Die Religion Der Griechen und Römer); Holme, C.E.P., Ed.; Dutton \& Co. Inc.: New York, NY, USA, 1962.

42. Westermarck, E. Ceremonies and beliefs connected with agriculture, certain dates of the solar year, and the weather. Öfversigt Fin Vetensk. Förhandlingar 1913, 54, 1-150.

43. Hilton-Simpson, M.W. Some Algerian Superstitions Noted among the Shawia Berbers of the Aurès Mountains and their Nomad Neighbours. Folklore 1915, 26, 225-254. [CrossRef]

44. Abu-Zahra, N. The Rain Ritual as Rites of Spiritual Passage. Int. J. Middle East. Stud. 1988, 20, 507-529. [CrossRef]

45. Turner, V. The Ritual Process.: Structure and Anti-Structure; Cornell University Press: New York, NY, USA, 1969.

46. Louis, A.; Sironval, M.M.; Tamezredt, A. A $14 \mathrm{Km}$ Au Sud-Ouest de Matmata. Rev. L'Occident Musulman Méditerranée 1972, 12, 96-104. [CrossRef]

47. Leach, E. Two Essays Concerning the Symbolic Representation of Time. In Rethinking Anthropology; The Athlone Press: London, UK, 1961; pp. 124-136.

48. Eliade, M. The Myth of the Eternal Return (Le Mythe de L'éternel Retour); Trask, W.R., Ed.; Princeton University Press: New York, NY, USA, 1974.

49. Kurano, K.; Takeda, Y. Kojiki Norito, Nihon Koten Bungaku Taikei; Iwanami Shoten: Tokyo, Japan, 1958 ; Volume 1. 